\title{
Education and Knowledge Management: Pedagogical Challenges
}

\author{
Adelcio Machado dos Santos* \\ Postgraduate Programs in Development and Society and Education, Universidade Alto Vale do Rio do \\ Peixe - UNIARP \\ Rua Prof. Egídio Ferreira, no 271, Apto. 303, Florianópolis (SC) 88090-699, Brasil \\ E-mail: adelciomachado@gmail.com \\ Alexandre Carvalho Acosta \\ Faculdade CENSUPEG \\ Avenida Barão do Rio Branco, 943, Caçador (SC), 89500-000, Brasil \\ E-mail: alexandre@alexandreacosta.com \\ Alisson Andre Escher \\ Student in the Master's program in Basic Education, Universidade Alto Vale do Rio do Peixe - UNIARP \\ Rua Victor Baptista Adami, 800, Caçador (SC) 89500-000, Brasil \\ E-mail: alissonandreescher@gmail.com \\ Inês Maria Gugel Dummel \\ Coordinator of the Distance Education Center, Universidade Alto Vale do Rio do Peixe - UNIARP \\ Rua Victor Baptista Adami, 800, Caçador (SC) 89500-000, Brasil \\ E-mail: ines.maria@uniarp.edu.br \\ Joel Haroldo Baade \\ Postgraduate Programs in Development and Society and Education, Universidade Alto Vale do Rio do \\ Peixe - UNIARP \\ Rua Guilherme Wegner,720, Brusque (SC) 88355-050, Brasil \\ E-mail: baadejoel@uniarp.edu.br
}

\begin{abstract}
The instructor of Knowledge Management in Higher Education needs the formation of a systematic process of pedagogical training, which allows him/her to develop his/her skills as an educator. Dealing with adult students does not exempt the university instructor from enabling practical application of the knowledge acquired in the classroom. The background of the study is the pedagogical practice of the authors at a university in the interior of Santa Catarina, one of the three southern Brazilian states. The students are from middle to lower classes, who mostly work during the day to finance their evening studies. Thus, in the teaching of Knowledge Management it is not enough for the instructor to have a mastery of the knowledge related to the subject he teaches. The instructor needs to develop the ability to create teaching material for students and strategies of different teaching methods, such as: the lecture; discussion; simulations and audiovisual resources. Despite all the preparation and planning of the instructor to teach the contents, the primary pedagogical tool is dialogue. The communication between teacher and students waives all the content of a class, because it depends on it that the learning happens. Keywords: Knowledge Management, Pedagogy, Higher Education.
\end{abstract}

DOI: $10.7176 /$ RHSS/10-8-01

Publication date: April $30^{\text {th }} 2020$

\section{Introduction}

In higher education, one of the most valued themes by instructors is pedagogical and preparatory training for instructors who work in the classroom. The research and the results of evaluations of the pedagogical processes carried out by the students have forced instructors to specialize in the disciplines they teach, in the multitasks that are assigned and in the new learning techniques (MORAN, 2000; GEIJO, 2008; FREITAS, 2010).

At the same time, the issue of knowledge management is increasingly an issue to be taken into account in spaces of knowledge construction, since more than producing new knowledge, it is currently necessary to know how to manage the wide range of information available. The development of communication technologies was fundamental in this process.

Thus, the present essay deals with the issue of knowledge management in teaching and learning spaces at a higher education level, asking for the central questions that should guide the pedagogical practice of professionals working at this level of education.

Methodologically, the study is qualitative and bibliographic, and can be characterized as a theoretical essay 
on the exposed theme. The text is structured in three main points: the first one deals with the essential characteristics of teaching in higher education; in the second one, the pedagogical challenges to teaching in higher education are discussed with a view to knowledge management; the approach ends with some final considerations on the topic addressed.

\section{Essential characteristics of teaching in higher education}

Firstly, it is essential that the knowledge management instructor has several characteristics, even though the list is incomplete, such as those pointed out by Gil (1997): emotional stability, versatility, initiative, self-confidence, discipline, patience, cooperation, rhythm stability, diffuse attention, abstract and verbal intelligence, memory, observation, quick and logical reasoning, imagination, association, among others.

In addition to these specific characteristics, the teacher must meet some technical requirements, as specified by Gil (1997):

a) Structure and functioning of higher education: the teacher must be able to establish relationships between what happens in the classroom with broader processes and structures. This implies an analysis of the objectives proposed by Brazilian higher education, as well as the problems that interfere with its implementation. And they demand knowledge related to the historical evolution of university institutions and the legislation that governs them;

b) Teaching planning: efficiency in teaching requires planning. The teacher needs to be able to predict the indispensable actions for the teaching to achieve their goals. This requires the careful preparation of a discipline plan and as many unit plans as necessary;

c) Teaching method: the adoption of teaching methods is essential to facilitate teaching and learning. Nowadays, there are countless teaching methods and it is advisable that the teacher knows the advantages and limitations of each method to use them in the most appropriate moments and ways;

d) Assessment techniques: teaching cannot be conceived without evaluation. It needs to have a formative character, developing throughout each discipline and aiming to facilitate learning. Thus, the instructor of higher education needs to be trained to develop an instrument for assessing knowledge and also the skills and attitudes of students.

All of these technical requirements need to be readapted by the teacher to suit the teaching of the knowledge management discipline. In this sense, it is essential that the teacher takes into account the pragmatics related to knowledge management. Only the theoretical study of concepts is insufficient for training in the discipline.

\section{Pedagogical Challenges in Teaching Knowledge Management}

Furthermore, when developing eventual knowledge management projects, students need to start from the reality of the business environments in which they operate, not considering knowledge management as something extraordinary. As Davenport and Prusak (1998) well observe, knowledge management is based on existing resources, which the organization may already be counting on, such as: good management of information systems, management of organizational change and good practices of human resource Management (GIFTSON, 2017).

If an organization, for example, has a textual database or even effective educational programs, it is certainly already doing an activity that could be called knowledge management (CACHO, 2019). From this, it is necessary that the student expands or improves these practices to be able to call himself knowledge manager.

Therefore, it is important that the teacher of the knowledge management discipline shows the student the importance of combining this management with the other activities of the organization. Otherwise, it is likely to be ineffective. The training of the student also needs to focus on the acknowledgment of working together in the organization when it comes to the implementation of knowledge management projects (CACHO, 2019).

In line with the teaching of Davenport and Prusak (1998), it is the organization as a whole that must make its own decisions regarding which knowledge is the most important to be managed, how to motivate people to share and use that knowledge and what will make a project successful in its own specific environment.

In knowledge management, it is important, as Davenport and Prusak (1998) point out, to start small projects. Knowledge management needs to start with a recognized organizational problem, related to knowledge. Loss of customers, poorly designed products, loss of key personnel or reduction in the winning rate of service contracts are all holistic problems that can be attributed to poor knowledge management (FERREIRA, 2019). Therefore, the instructor of the knowledge management discipline needs to show that attacking these problems, identifying their knowledge component and using the value to address them as a justification for knowledge efforts are good ways of dealing with knowledge management.

The most relevant factors in the opportunity to decide where to start is the importance of the specific area of knowledge for the company and the viability of the project. Knowledge management can also involve a lot of abstract activity that is sometimes not paid for in terms of modified behavior and tangible results. Knowledge 
mapping, for example, can take a long time and a large amount of money, especially if performed with a high level of detail. Here it is important that the instructor makes it clear to the student the relevance of starting in a small area of the company - creating a knowledge map in the smallest details of a relatively circumscribed area of knowledge (FERREIRA, 2019).

The pragmatics in the teaching of knowledge management presupposes, therefore, the conciliation with planning, by the teacher, of different teaching methods, such as: lecture; discussion; simulations and audiovisual resources. Only by combining different teaching methods will it be possible to train a student capable of developing knowledge management projects, and not just a theoretical expert on the topic (FERREIRA, 2019).

It should be noted that, when planning the discipline of knowledge management, the teacher also covers the following aspects of the student's education, pointed out by Zabalza (2004):

a) New possibilities for personal development: personal development involves, above all, balanced personal growth, the improvement of the individual's basic abilities and personal satisfaction, the enrichment of selfesteem and the feeling of being more and more competent and of being in better conditions to accept challenges present in life and not only professional ones;

b) New knowledge: it concerns the idea of obtaining more knowledge and being more competent as a result of the continuous training process;

c) New skills: the skills refer to the development of the interventional capacity in certain realities, the individual being able to develop certain activities better than they did before;

d) Attitudes and values: this is a substantial part of any training process, although it is currently the most absent content in such processes. Attitudes and values can refer to the people themselves or to others, such as coworkers, events and situations of daily life and commitments made or the way of guiding work;

e) Enrichment of experiences: training should constitute, as a whole, an opportunity to expand the repertoire of experiences of the participating individuals.

According to Gil (1997), the lecture is characterized by the verbal lecture employed by teachers in order to transmit information to their students. Its limit lies in the fact that, when exposing the material, oftentimes, the teacher neglects the importance of the student's interest and attention, which is not always able to capture the message being transmitted.

Thus, the discussion becomes essential because it allows the questioning of what is exposed by the teacher and by the students themselves. According to Gil (1997, p. 78), the discussion responds to several objectives, such as:

a) encourage reflection on knowledge obtained through reading or exposure;

b) develop new knowledge by using previous knowledge and experience;

c) favor the approach of a subject from different angles;

d) give students the opportunity to formulate principles in their own words and suggest applications for those principles;

e) helping students to become aware of the problems that appear in the information obtained from readings;

f) facilitate the acceptance of information or theories contrary to traditional beliefs or previous ideas.

For these reasons, the discussion has been recommended as one of the most relevant teaching strategies, as sustains Gil (1997). In addition, a successful discussion can be significantly enjoyable for both students and teachers, constituting an exercise of freedom and autonomy in the classroom.

With regard to simulations, they have a fundamental role in the discipline of knowledge management, since they allow the student to apply the acquired knowledge in practice. Gil (1997) states that through the simulation strategy the student assumes a certain role that exists in real life and behaves according to that role. The consequences of performing these roles are perceived by students, who are asked to reflect on this. Therefore, they are strategies that place the student very close to real situations and allow immediate feedback on consequences of their behaviors, attitudes and decisions (FREITAG; FISCHER, 2017).

Audiovisual resources overcome the problem of teachers' verbalism, that is, the transmission of knowledge and skills through the exaggerated use of the word. As a consequence of this verbalism, much of what is passed on to students in class consists of empty and meaningless words. In view of the limitations of verbal explanations and aiming to make communication clearer and more precise, many teachers resort to resources known as audiovisuals, ranging from simple drawings or diagrams to sophisticated equipment and multimedia softwares. In the context of knowledge management, audiovisual resources are important tools that are made available to teachers to facilitate teacher communication.

All these methodologies, among others that each instructor can choose according to the need, and whose practice becomes a real challenge to be faced by the knowledge management educator, allow to achieve dynamism in the classroom.

Rangel (2005, p. 85) points out that "the essential dynamism and the essential of the dynamism of the classroom are located in the irreplaceable relationship between people who communicate and communicate knowledge". Thus, whatever the methodology, it does not do without communication and depends directly on it 
for the learning to take place. Furthermore, the clearer, more didactic, more explicit, more objective and more oriented the communication, the more effective the methodology will be. This means that there is a direct relationship between the quality of communication and the result of the methodological process.

Teaching-learning takes place in a social situation, whether due to dialogue and interaction, whether due to communication being a requirement, or because it takes place through the process of re-elaborating knowledge, inherent to cultural, aesthetic, ethical values, which characterize human formation (RANGEL, 2005).

Didactic communication is favored by maximum clarity and minimum noise, requiring, from the sender, the connection between thought and language. This connection, on the other hand, is favored by the domain of the subject. The clarity of didactic communication, on the other hand, is favored by the teacher's attention to objectivity, the essentiality of the content, the elucidation of meanings, the interest of students, their understanding, among other factors. In this same perspective, when forwarding the didactic exhibition, the relevance of contextualizing, developing concepts, arguing, explaining processes, presenting examples, concluding, synthesizing and reviewing is perceived. All these aspects make up the scenario of dynamizing the teaching and learning environment.

\section{Final considerations}

The pedagogical challenges faced by the instructor of the subject of Knowledge Management in Higher Education involve since the production of didactic material, the definition of teaching methods, combining them for the knowledge management pragmatics, in addition to adapting them to the objectives of the education.

When teaching Knowledge Management classes, according to the objectives of the discipline, the instructor needs to combine and develop strategies for building the desired content, as well as attending to the other activities of the organization, simulating practical learning exercises in the specific area of knowledge.

Despite all the preparation and planning of the instructor to teach the contents and the student's expectation for knowledge, the primary pedagogical tool is dialogue. Communication between teacher and student dispenses with the entire content of a class, as learning depends on it.

The analysis undertaken points to the need for more empirical research regarding the knowledge management instructor. It would be important to map the pedagogical practices and resources used by these teachers. The understanding of these experiences based on reports and questionnaires applied to teachers is also irrevocable. Equally fundamental, research applied to students is indicated, in order to understand the learning experience, difficulties and positive aspects of the practices proposed in the view of these students. It can be seen, therefore, that the proposed problem has numerous consequences and is of great relevance for the development of science in this field.

\section{References}

CACHO, A. N. B. (2019). A gestão do conhecimento e redes interorganizacionais em organizações públicas de turismo. Dissertation (Doctorate in Tourism and Management) - Natal: Postgraduate in Tourism, Federal University of Rio Grande do Norte. 2019. Available on: https://repositorio.ufrn.br/jspui/bitstream/123456789/28486/1/Gestaoconhecimentoredes_Cacho_2019.pdf. Access on: 10 feb. 2020.

DAVENPORT, T. H.; PRUSAK, L. (2003). Conhecimento empresarial: como as organizações gerenciam o seu capital intelectual. 14 ed. Rio de Janeiro: Elsevier, 2003.

FERREIRA, A. B. A. (2010). A gestão de conhecimento e o desenvolvimento de recursos humanos: revisão sistemática da literatura produzida no séc. XXI. Thesis (Masters in Human Resources Management). Lisbon: University of Lisbon, 2019. Available on: https:/www.repository.utl.pt/bitstream/10400.5/19665/1/DMABAF-2019.pdf. Access on: 10 feb. 2019.

FREITAG, B. B; FISCHER, A. L. (2017). Talentos em gestão e gestão de talentos: análise da literatura acadêmica e de práticas corporativas. REAd, Porto Alegre, v 23, n. esp., p. 158-87. Available on: http://www.scielo.br/pdf/read/v23nspe/1413-2311-read-23-spe-158.pdf. Access on: 15 feb. 2020.

FREITAS, Maria Teresa (2010). Letramento Digital e Formação de Professores. Educação em Revista, Belo Horizonte, v. 26, n. 3, p. 335-352. Available on: https://doi.org/10.1590/S0102-46982010000300017. Access on: 22 apr. 2020.

GEIJO, Pedro Martìnez (2008). Estilos de aprendizaje: pautas metodológicas para trabajar en el aula. Revista Complutense de Educacion, v. 19, n. 1, p. 77-94, 2008. Available on: https://core.ac.uk/download/pdf/38820741.pdf. Access on: 22 apr. 2020.

GIFTSON, T. (2017). Knowledge Management Practices - A Human Resource Perspective. Research on Humanities and Social Sciences, v.7, n. 17, p. 32-34. Available on: https://iiste.org/Journals/index.php/RHSS/article/view/38500/39584. Access on: 10 feb. 2020.

GIL, A.C. (1997). Metodologia do ensino superior. São Paulo: Atlas.

MORAN, José Manuel (2000). Ensino e aprendizagem inovadores com tecnologias. Informática na educação: 

prática, $\quad \mathrm{v}$ 3,

$\mathrm{n}$.

1, 2000.

2000. Available

on: https://seer.ufrgs.br/InfEducTeoriaPratica/article/view/6474/3862. Access on: 22 apr. 2020.

RANGEL, M. (2005). Métodos de ensino para a aprendizagem e a dinamização das aulas. Campinas: Papirus. ZABALZA, M. A. (2004). O ensino universitário: seus cenários e seus protagonistas. Porto Alegre: Artmed. 